\title{
Comparison between Xylazine-Tiletamine-Zolazepam and Fentanyl-Tiletamine- Zolazepam Anaesthetic Combinations on Plasma Oxidative Status in Sheep
}

\author{
N. AYDILEK \\ Harran University, Faculty of Veterinary Medicine, Department of Physiology \\ Sanliurfa, Turkey \\ Received April 10, 2007 \\ Accepted October 2, 2007
}

\begin{abstract}
Aydilek N.: Comparison between Xylazine-Tiletamine-Zolazepam and Fentanyl-TiletamineZolazepam Anaesthetic Combinations on Plasma Oxidative Status in Sheep. Acta Vet. Brno 2007, 76: $573-578$.

It is important to determine varying effects of anaesthetics agents. One of the adverse effects of general anaesthetics are the exogenous sources of reactive oxygen species. In this study, the effects of xylazine-tiletamine-zolazepam (XTZ) and fentanyl-tiletamine-zolazepam (FTZ) combinations on plasma oxidant-antioxidant indicators were compared in sheep. Ten ewes received two different anaesthetic combinations in a ten-day interval. XTZ group was injected with xylazine and tiletamine-zolazepam. FTZ group was injected with fentanyl and tiletamine-zolazepam. Blood samples were collected before and at the 30,60, $120 \mathrm{~min}, 24 \mathrm{~h}$ and 3 days after anaesthesia. Both anaesthetic regimens caused an increase in malondialdehyde (MDA) concentrations in plasma. The MDA concentrations at 60,120 min and $24 \mathrm{~h}$ in the XTZ group were significantly higher than in the FTZ group. Glutathione (GSH) concentration at 30, 60, $120 \mathrm{~min}$ and $24 \mathrm{~h}$ was significantly lower than baseline values in XTZ group, while there was only a decrease at 120 min in the FTZ group. GSH concentrations in the XTZ group were significantly lower at 60 and 120 min compared with the FTZ group. Beta carotene concentration was decreased at 120 min and $24 \mathrm{~h}$ in the XTZ group, while it decreased only at $120 \mathrm{~min}$ in the FTZ group. Glutathione peroxidase (GSH-Px) and catalase (CAT) activities decreased at $120 \mathrm{~min}$ and $24 \mathrm{~h}$ only in the XTZ group. There were no significant differences in $\beta$-carotene concentration, activities CAT and GSH-Px activities between groups. In conclusion, both XTZ and FTZ anaesthetic regimens induced oxidative stress in sheep. XTZ combination has more detrimental effect than FTZ combinations on particularly MDA and GSH concentrations. Therefore, FTZ anaesthetic combination is considered to be more suitable for sheep anaesthesia, due to less deteriorating effects on oxidant/antioxidant balance.
\end{abstract}

Anaesthesia, oxidative status, sheep

General anaesthesia is commonly used for surgical manipulations in small ruminants. An anaesthetic regimen with minimal side effects is desirable when anaesthesia is required for longer than $1 \mathrm{~h}$ in sheep (Lagutchik et al. 1991). One of the undesirable complications of general anaesthetics can be induced by reactive oxygen species (ROS) that occur during anaesthesia (Godin and Garnett 1994). Reactive oxygen species are produced as by-products of metabolism. In organisms, enzymatic (superoxide dismutase, catalase, glutathione peroxidase) and non-enzymatic (urate, cysteine, vitamin E, vitamin C, $\beta$-carotene) antioxidant defence systems maintain ROS concentrations in the physiological range. Oxidative stress occurs when the balance between ROS and antioxidants defence is disturbed. ROS cause cellular destruction by oxidative damage of DNA, proteins, lipids and carbohydrates, by changing the structure and function of key cellular constituents that result in mutation, cell damage and death (Simeonova et al. 2004). Thus, ROS play an important role in the pathogenesis of different diseases such as inflammation, carcinogenesis and ischemia-reperfusion (Jacinto et al. 1996; Chandra et al. 2000).

Anaesthesia always provokes a stress reaction accompanied by neurohumoral and metabolic responses for maintaining homeostasis. The impact of anaesthesia on the

Address for correspondence:

Dr. Nurettin AYDİLEK

Harran University

Faculty of Veterinary Medicine

Department of Physiology

Phone: 0090414-312 8456 (ext 2436)

Fax: 00904143144158

63100 Sanliurfa, TURKEY

E-mail: naydilek@hotmail.com

http://www.vfu.cz/acta-vet/actavet.htm 
development of oxidative stress and consequent post-anaesthetic complications has been poorly studied in veterinary medicine. Some studies found increased radical generation during general anaesthesia with halothane (Neri et al. 1993) and isoflurane (Naziroglu and Gunay 1999); whereas in other studies it was shown that some anaesthetics, such as propofol, had antioxidant properties (Runzer et al. 2002).

Although XTZ and FTZ anaesthetic combinations were reported to produce safe and adequate anaesthesia in a previous study on sheep (Ceylan et al. 2007a), to our knowledge there has been no study reporting the effect of TZF and TZX anaesthetic combinations in plasma oxidant/antioxidant indicators in sheep. Therefore, this study was conducted to find the most suitable anaesthetic combination with regard to the oxidant/antioxidant indicators in patients that already have a tendency for oxidative stress under surgical intervention.

\section{Materials and Methods}

Ten healthy Awassi ewes, 3 - 4 years old, of body mass ranging from 35 to $45 \mathrm{~kg}$, were used in this study. Physical examination and serum biochemical analyses 2 days before the study were within the physiological limits in all sheep. All ewes received two different anaesthetic drug combinations. There was an interval of 10 days between anaesthetic treatments in each sheep. XTZ group was injected with $0.2 \mathrm{mg} \cdot \mathrm{kg}^{-1}$ of xylazine (Rompun $^{\circledR}$, Bayer, Turkey) and $7.5 \mathrm{mg} \cdot \mathrm{kg}^{-1}$ of tiletamine-zolazepam (Zoletil $50^{\circledR}$, Virbac, France). FTZ group was injected with fentanyl (Fentanyl Citrate ${ }^{\mathbb{R}}$, Abbott, USA) $10 \mu \mathrm{g} \cdot \mathrm{kg}^{-1}$ and $7.5 \mathrm{mg} \cdot \mathrm{kg}^{-1}$ of tiletamine-zolazepam. All drugs were administered intramuscularly. The sheep, breathing spontaneously room air without intubation were placed in lateral recumbence. No excitement was observed during anaesthesia.

Blood samples were collected by jugular venipuncture into vacutainer containing EDTA before (baseline) and at 30,60, $120 \mathrm{~min}, 24 \mathrm{~h}$ and 3 days after anaesthesia. The samples were immediately centrifuged at $1500 \mathrm{~g}$ for 10 min and plasma samples were stored at $-80^{\circ} \mathrm{C}$ until measuring of the following indicators:

The concentration of MDA, the end-product of polyunsaturated fatty acid peroxidation in plasma was determined at $532 \mathrm{~nm}$ by using a spectrophotometer (Jainway 6100, UK) according to the method of Placer et al. (1966) modified by Matkovics et al. (1988). Glutathione level was measured according to the method of Sedlak and Lindsay (1968), by using 5,5'dithio-bis-2-nitrobenzoic acid for colour development at $412 \mathrm{~nm}$ with spectrophotometer. Glutathione peroxidase activity was measured at $421 \mathrm{~nm}$ as described by Lawrence and Burk (1976). Catalase activity was determined according to the method of Goth (1991). The levels of $\beta$-carotene in samples were determined according to the method of Suzuki and Katoh (1990).

Statistical analyses were performed on SPSS software, 10.0.1 (SPSS Inc. Chicago, IL, USA). Data were analyzed using General Linear Model (GLM) for repeated measures and Wilcoxon signed rank test was used to examine changes within time intervals in each group. Significant differences were defined as $p<0.05$.

\section{Results}

All sheep recovered from anaesthesia without complications and no excitement was observed during anaesthesia. MDA concentration increased at $60,120 \mathrm{~min}$ and $24 \mathrm{~h}$ in the XTZ group $(p<0.05)$, on the other hand, its concentration increased $(p<0.05)$ at 60 and $120 \mathrm{~min}$ in the FTZ group (Table 1). GSH concentration significantly decreased $(p<0.05)$ at 30,60, $120 \mathrm{~min}$ and $24 \mathrm{~h}$ in XTZ group, while it decreased $(p<0.05)$ only at 120 min in the FTZ group. Especially, GSH concentration in the FTZ group was significantly higher $(p<0.05)$ than in the XTZ group at the 60 and $120 \mathrm{~min}$. Beta carotene concentration significantly decreased $(p<0.05)$ at $120 \mathrm{~min}$ and $24 \mathrm{~h}$ in the XTZ group, while its concentration decreased only $(p<0.05)$ at $120 \mathrm{~min}$ in the FTZ group. No significant differences were observed in $\beta$-carotene concentrations between groups. The activities of GSH-Px and CAT significantly decreased $(p<0.05)$ at 60 and $120 \mathrm{~min}$ in XTZ group; however, there were no significant changes in the FTZ group. On the other hand, no significant differences were observed in CAT and GSHPx activities between groups.

\section{Discussion}

Oxidative stress resulting from an imbalance of oxidant/antioxidant status is one of the harmful effects related to anaesthetic regimen during surgical procedures. We evaluated plasma 


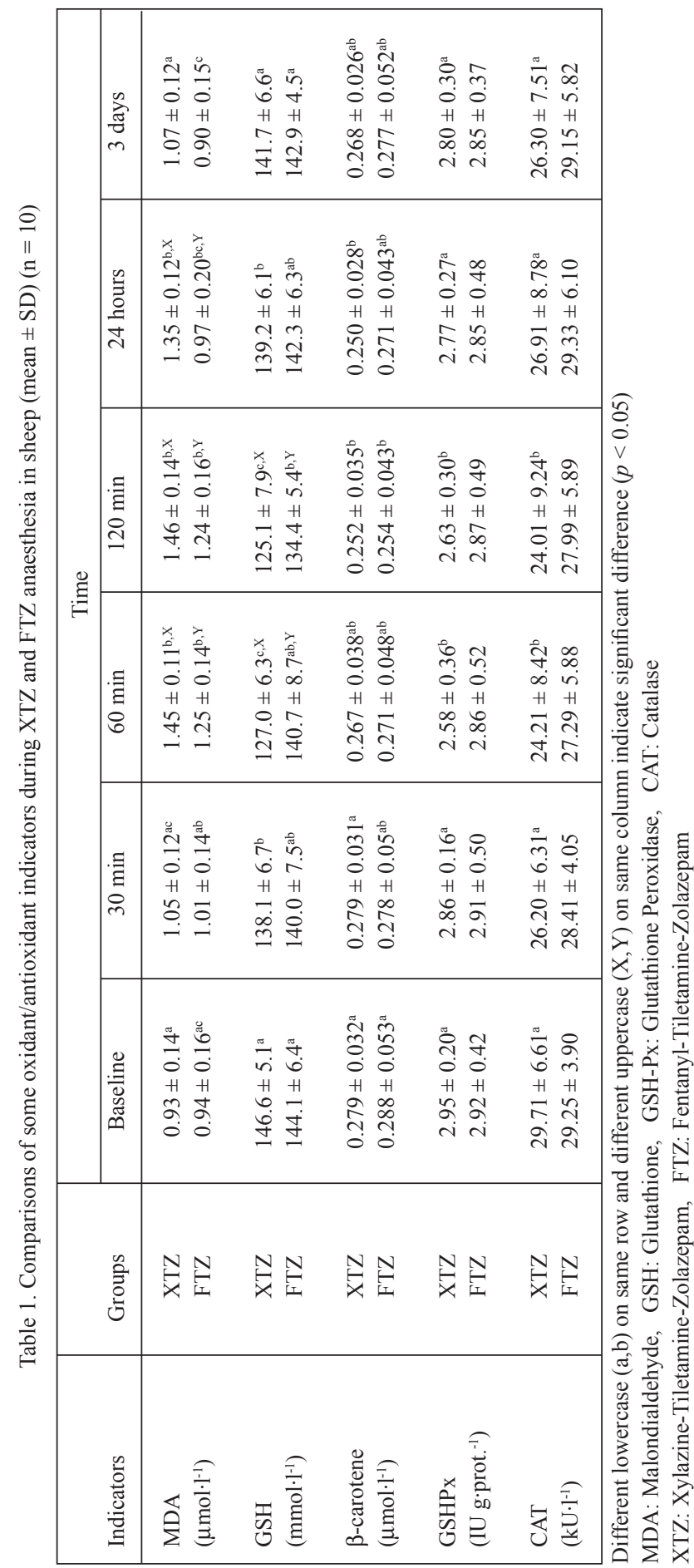

oxidant/antioxidant status during general anaesthesia established with XTZ and FTZ anaesthetic combinations in sheep.

A wide variety of anaesthetic drugs and xenobiotics are themselves either converted to, or stimulate the formation of ROS. Ceylan et al. (2007b) reported that tiletamine-zolozepam anaesthesia alone induced lipid peroxidation in plasma of sheep. Similarly, a significant elevation in the MDA levels, index of lipid peroxidation in response to both anaesthetic administrations was noticed in the current study (Table 1). Particularly, the MDA concentrations in the XTZ group were significantly higher $(p<$ 0.05 ) than in the FTZ group at $60,120 \mathrm{~min}$ and $24 \mathrm{~h}$. In other words, XTZ anaesthesia more seriously disrupted the balance of oxidant/antioxidant in plasma. This difference can be attributed to the activities of fentanyl or xylazine on ROS production. Chinev et al. (1998) reported that fentanyl and droperidol did not induce lipid peroxidation in rat lungs when used separately or in combination with nitrous oxide. But, injection of fentanyl or droperidol before nitrous oxide significantly reduced prooxidant action of nitrous oxide and was able to inhibit the $\mathrm{Fe}^{+2}$-catalysed lipid peroxidation in the lung of rats. Furthermore, lipid peroxidation level in the liver of the rats injected with droperidol and fentanyl was low and close to that of the control rats (Chinev et al. 1995). Thus, lower lipid peroxidation level 
in the FTZ group may be a result of the activity of fentanyl in the current study. On the other hand, higher oxidative stress in the XTZ group may also be attributed to hyperglycaemia due to the inhibition of insulin release from pancreatic $\beta$ cells by xylazine (Hsu and Hummel 1981). In previous studies, acute hyperglycaemia was reported to cause oxidative stress by various mechanisms in humans (Marfella et al. 2001) and rats (Kyselova et al. 2002). In the current study, the level of glucose increased at 30, 60, $120 \mathrm{~min}$ and $24 \mathrm{~h}$ in ewes anaesthetized with XTZ combination $(p<0.05)$; similarly, Sindak et al. (2003) reported that XTZ anaesthesia induced hyperglycaemia in Holstein calves. As for FTZ anaesthesia, it caused no changes in the glucose level in the current study (data not shown). The results suggest that the higher oxidative stress may also have resulted from the elevated glucose level in the XTZ group.

Glutathione is an endogenous protective agent that plays a critical role in intracellular antioxidant defence. GSH efficiently scavenge ROS and detoxifies various chemicals by forming conjugate with these harmful substances (Yang et al. 1997). Furthermore, it is a cofactor for GSH-Px and is required for recycling ascorbate or vitamin E (Smith et al. 1990). GSH concentrations showed a significant decline $(p<0.05)$ in both anaesthetic combination groups. When compared with the FTZ group, GSH concentrations in the XTZ group were significantly lower $(p<0.05)$ at 60 and $120 \mathrm{~min}$. The decrease in GSH concentration in both groups may have resulted from rapid reacting with lipid peroxidation products, generated during the metabolism of these anaesthetics or consumed by GSH-Px activity. Because oxidative stress in the XTZ group was significantly higher $(p<0.05)$ than in FTZ group, GSH levels may have been more diminished by ROS in the XTZ group.

Beta carotene, a precursor of vitamin A, is recognized as efficient scavenger of singlet oxygen. Particularly, it can exert antioxidant function at low oxygen tension (Ozhogina and Kasaikina 1995). Beta carotene concentration decreased at $120 \mathrm{~min}$ and $24 \mathrm{~h}$ in the XTZ group $(p<0.05)$, while it decreased only at $120 \mathrm{~min}$ in the FTZ group $(p<0.05)$. These results suggested that $\beta$-carotene was consumed by ROS as a consequence of elevated lipid peroxidation.

GSH-Px and CAT activities decreased at 60 and $120 \mathrm{~min}$ in the XTZ group $(p<$ 0.05 ). Slight decreases in GSH-PX and CAT in FTZ group were not significant. The decreases in GSH-Px and CAT activities were accompanied by increased oxidative stress. It is known that GSH-Px and CAT detoxify hydrogen peroxide and convert lipid hydroperoxides into non-toxic alcohols (Halliwell and Gutteridge 1996). The decreases in plasma GSH-Px and CAT activities may be due to inactivation of the enzymes by hydrogen peroxide.

In summary, both XTZ and FTZ anaesthetic administration induced oxidative stress in sheep. However, FTZ anaesthesia had less detrimental effects on particularly MDA and GSH concentrations. Due to less deteriorating effects on oxidant/antioxidant balance, FTZ anaesthetic combination is considered to be more suitable for sheep anaesthesia.

\section{Srovnání anestetikých kombinací Xylazin-Tiletamin-Zolazepam a Fentanyl-Tiletamin-Zolazepam na oxidační status plasmy u ovcí}

Je důležité zjišt'ovat rozdíly v účincích anestetických látek. Jednou z nežádoucích vlastností celkových anestetik je to, že jsou exogenní příčinou vzniku reaktivních kyslíkových forem. V této studii byl u ovcí porovnáván vliv kombinace xylazin-tiletaminzolazepam (XTZ) a fentanyl-tiletamin-zolazepam (FTZ) na plazmatické koncentrace indikátorů oxidativního stresu. Deseti bahnicím byly aplikovány dvě různé kombinace anestetik v desetidenních intervalech. Skupině XTZ byl podáván xylazine a tiletaminzolazepam. Skupině FTZ byl podáván fentanyl a tiletamin-zolazepam. Vzorky krve byly odebrány před, 30, 60, 120 min, 24 h a 3 dny po anestezii. Koncentrace MDA 60, 
120 min a 24 h po aplikaci u skupiny XTZ byly signifikantně vyšší než u skupiny FTZ. Koncentrace glutathionu (GSH) $30,60,120$ min a 24 h po aplikaci byly signifikantně nižší než bazální hodnoty u skupiny XTZ, zatímco u skupiny FTZ došlo k poklesu pouze ve 120 . min. Koncentrace GSH u skupiny XTZ byly oproti skupině FTZ signifikantně nižší v 60. a 120. min. Koncentrace $\beta$-karotenu skupiny XTZ poklesla ve 120. min a po $24 \mathrm{~h}$, zatímco u skupiny FTZ došlo k poklesu pouze po $120 \mathrm{~min}$. Aktivity glutathion peroxidázy (GSH-Px) a katalázy (CAT) poklesly ve 120. min a v 24. h pouze u skupiny XTZ. U všech skupin nebyly významnější rozdíly v koncentraci $\beta$-karotenu, aktivitách CAT a GSH-Px. Anestetické schéma XTZ i FTZ vyvolává u ovcí oxidativní stres. Kombinace XTZ měla škodlivější účinky než FTZ zejména na koncentrace MDA a GSH. Vzhledem k menšímu narušování rovnováhy oxidantů a antioxidantů, je kombinace FTZ považována za vhodnější k anestezii ovcí.

\section{References}

CEYLAN C, IPEK, HAYAT A, AYDILEK N 2007a: The anaesthetic effects of tiletamine-zolazepam alone and in combination with xylazine or fentanyl in sheep. Indian Vet J 84: 38-40

CEYLAN C, AYDILEK N, IPEK H 2007b: Effects of tiletamine-zolazepam anesthesia on plasma antioxidative status and some haematological parameters in sheep. Acta Vet Hung 55: 191-197

CHANDRA J, SAMALI A, ORRENIUS S 2000: Triggering and modulation of apoptosis by oxidative stress. Free Radic Biol Med 29: 323-333

CHINEV S, BAKALOVA R, PENEVA V, UZUNOVA P, GALABOVA T, SOKOLOVA Z, RIBAROV S 1995: Nitrous oxide with fentanyl and droperidol minimizes lipid peroxidation in the liver. Eur J Anaesthesiol 12: $155-162$

CHINEV S, BAKALOVA R, KOVACHEVA S, RIBAROV SR 1998: Lipid peroxidation in rat lung induced by neuroleptanalgesia and its components. Eur J Anaesthesiol 15: 686-694

GODIN DV, GARNETT ME 1994: Effects of various anesthetics regimens on tissue antioxidant enzyme activities. Res Commun Chem Pathol Pharmacol 83: 93-101

GOTH L 1991: A simple method for determination of serum catalase activity and revision of reference range. Clin Chim Acta 196: 143-157

HALLIWELL B, GUTTERIDGE JM 1996: Protection against oxidants in biological systems: the superoxide theory of oxygen toxicity. In: HALLIWELL B, GUTTERIDGE JM (Ed.): Free Radicals in Biology and Medicine. Clarendon Pres, Oxford, pp. 86-187

HSU WH, HUMMEL SK 1981: Xylazine-induced hyperglycemia in cattle: a possible involvement of $\alpha_{2}-$ adrenergic receptors regulating insulin release. Endocrinology 109: 825-829

JACINTO SM, LOKHANDWALA MF, JANDHYALA BS 1996: Effect of pharmacological interventions in the prevention of lipid peroxidation and respiratory depression induced by oxygen free radicals in anaesthetized rats. Free Radic Biol Med 21: 791-799

KYSELOVA P, ZOUREK M, RUSAVY Z, TREFIL L, RACEK J 2002: Hyperinsulinemia and oxidative stress. Physiol Res 51: 591-595

LAGUTCHIK MS, JANUSZKIEWICZ AJ, DODD KT, MARTIN DG 1991: Cardiopulmonary effects of a tiletamine-zolazepam combination in sheep. Am J Vet Res 52: 1441-1447

LAWRENCE RA, BURK RF 1976: Glutathione peroxidase activity in selenium-deficient rat liver. Biochem Biophys Res Commun 71: 952-958

MARFELLA R, QUAGLIARO L, NAPPO F, CERIELLO A, GIUGLIANO D 2001: Acute hyperglycemia induces an oxidative stress in healthy subjects. J Clin Invest 108: 635-636

MATKOVICS B, SZABO L, VARGA I 1988: Determination of enzyme activities in lipid peroxidation and glutathione pathways (in Hungarian). Lab Diag 15: 248-250

NAZIROGLU M, GUNAY C 1999: The levels of some antioxidant vitamins, glutathione peroxidase and lipoperoxidase during the anesthesia of dogs. Cell Bicohem Funct 17: 207-212

NERI S, D'AMICO R, ANGELO G, NICOSIA A, AMICO A, MORGAN R 1993: Oxidative stress in patients undergoing general anaesthesia. Minerva Med 84: 183-186

OZHOGINA O, KASAIKINA O 1995: $\beta$-carotene as an interceptor of free radicals. Free Radic Biol Med 19: 575-581

PLACER ZA, CUSHMAN L, JOHNSON BC 1966: Estimation of products of lipid peroxidation (malonyldialdehyde) in biochemical systems. Anal Biochem 16: 359-64

RUNZER TD, ANSLEY DM, GODIN DV, CHAMBERS GK 2002: Tissue antioxidant capacity during anesthesia: propofol enhances in vivo red cell and tissue antioxidant capacity in rat model. Anesth Analg 94: 89-93

SEDLAK J, LINDSAY RHC 1968: Estimation of total, protein bound and non-protein sulfhydryl groups in tissue with Ellmann's reagent. Anal Biochem 25: 192-205 
SIMEONOVA GP, TODOROVA II, GADJEVA V, DINEV DN 2004: Evaluatin of lipid peroxidation associated with three anesthetic protocols in dogs. Revue Med Vet 155: 602-605

SINDAK N, YUREKLI UF, SERTKAYA H, SAKAR M 2003: Anaesthesia of tiletamine-zolazepam-xylazine and ketamine-xylazine in the calf. Turk J Vet Anim Sci 27: 775-779

SMITH LJ, ANDERON J, SHAMSUDDIN M, HSUEH W 1990: Effect of fasting on hyperoxic lung injury in mice: the role of glutathione. Am Rev Respir Dis 141: 141-149

SUZUKI J, KATOH N 1990: A simple and cheap method for measuring vitamin A in cattle using only a spectrophotometer. Jpn Vet Sci 52: 1282-1284

YANG CS, CHEN WY, TSAI PJ, CHENG FC, KUO JS 1997: Effect of diethylmaleate on liver extracellular glutathione levels before and after global liver ischemia in anesthetized rats. Biochem Pharmacol 53: 357-61 